\title{
Genetic Differences in Resistance of Range Grasses to the Bluegrass Billbug, Spheno- phorus parvulus (Coleoptera: Curculionidae)
}

\author{
K.H. ASAY, J.D. HANSEN, B.A. HAWS, AND P.O. CURRIE
}

\section{Abstract}

Significant differences in plant resistance to larvae of the bluegrass billbug, Sphenophorus parvulus Gyllenhal (Coleoptera: Curculionidae), were found among and within range grass species and interspecific hybrids in nurseries at the Decker, Mont., surface mine and on a site near Miles City, Mont. Slender wheatgrass (Elymus trachycaulus) and related species were particularly susceptible. Crested wheatgrass (Agropyron cristatum and $\boldsymbol{A}$. desertorum), thickspike wheatgrass (E. lanceolatus), Russian wildrye (Psathyrostachys juncea), and salina wildrye (Leymus salinae) were among the species with a relatively high degree of resistance to the insect. Clonal lines of the Et. repens $\times E$ Et. spicata hybrid differed significantly in resistance. Over $50 \%$ of the total phenotypic variation among the hybrid lines was attributed to genetic effects, indicating that selection for resistance would be effective.

Billbugs, Sphenophorus spp. (Coleoptera: Curculionidae), are serious pests on many pasture grasses (Satterthwait 1931). Both the bluegrass billbug ( $S$. parvulus Gyllenhal) and the hunting billbug ( $S$. venatus vestitus Chittenden) begin their development inside the stems of grass plants. After hatching, the early instars feed internally and later the older larvae move to the roots where pupation occurs (Tashiro and Personius 1970, Kamm 1969). Although feeding by adults causes damage, the last instars are the most destructive stage and the cumulative injury to the plant becomes most evident in late summer.

Chemicals have been proposed and tested for controlling billbugs in lawns and in grass seed production fields (Kamm and Every 1969, Brussell and Clark 1968, Tashiro and Personius 1970). However, resistance by the billbugs to cyclodiene insecticides was reported in Ohio (Niemczyk and Frost 1978) and the cost of application is prohibitive on western rangeland. An alternative strategy is to develop cultivars of grasses that are resistant to billbug feeding injury. Resistance to the bluegrass billbug has been observed in Kentucky bluegrass (Poa pratensis) (Kindler and Kinbacher 1975). Documentation of genetic factors conditioning resistance to this potentially damaging insect pest would be a major contribution to the development of improved grass cultivars for revegetating disturbed and depleted rangeland.

\section{Methods}

As part of a USDA-ARS breeding program to develop grass cultivars for revegetating areas disturbed by surface mining operations (Asay 1979), 2 space planted nurseries ( $A$ and $B$ ) were estab-

Authors are research geneticist, research entomologist, USDA-ARS, and professor, respectively, Utah State University, Logan 84322; and range scientist, USDA-ARS, U.S. Range Livestock Experiment Station, Miles City, Mont. 59301.

This article is a cooperative investigation of the USDA-ARS and the Utah Agricultural Experiment Station, Logan, Utah 84322. Approved as Journal Paper No. 2752. Manuscript received July 6, 1982 lished on reclaimed spoils of the Decker, Mont., surface mine. Nursery A consisted of 515 accessions representing 62 species and interspecific hybrids. Plots in this 8,240-plant nursery consisted of 8 plants each. Nursery B comprised 23 entries (Table 1 ) arranged in plots of 10 plants each. In both nurseries, plants were established on $0.5 \times 1.0 \mathrm{~m}$ centers and the single row plots were organized as randomized complete blocks with 2 replications.

In cooperation with Utah State University, the USDA-ARS is actively involved in a breeding program to develop fertile and stable cultivars from germplasm generated through interspecific hybridization (Asay et al. 1978). The most promising of these is the hybrid between quackgrass, Elytrigia repens, and bluebunch wheatgrass, Et. spicata, (Dewey 1976, Asay and Dewey 1981). During May 1, 46 clonal lines of this population (designated as the RS hybrid) were established on a nursery on a semiarid site near Miles City, Mont. Single-plant plots were arranged in the nursery on $1.0-\mathrm{m}$ centers as a randomized complete block with 10 replications. This design permitted the quantification of the relative magnitude of the genetic variation among the clonal lines for resistance to the insect. The percent genetic variability on a mean basis was computed as $\sigma_{\mathrm{C}}^{2} / \sigma_{\mathrm{h}}^{2}$, where $\sigma_{\mathrm{C}}^{2}$ was the genetic variance among clonal means and $\sigma_{\mathrm{F}}^{2}$ was the total phenotypic variance among the 46 entries.

The relative amount of damage caused by the billbug was determined in the nurseries at Decker and Miles City as natural infestations occurred. Plants were rated on a 0 to 9 scale, with 0 indicating

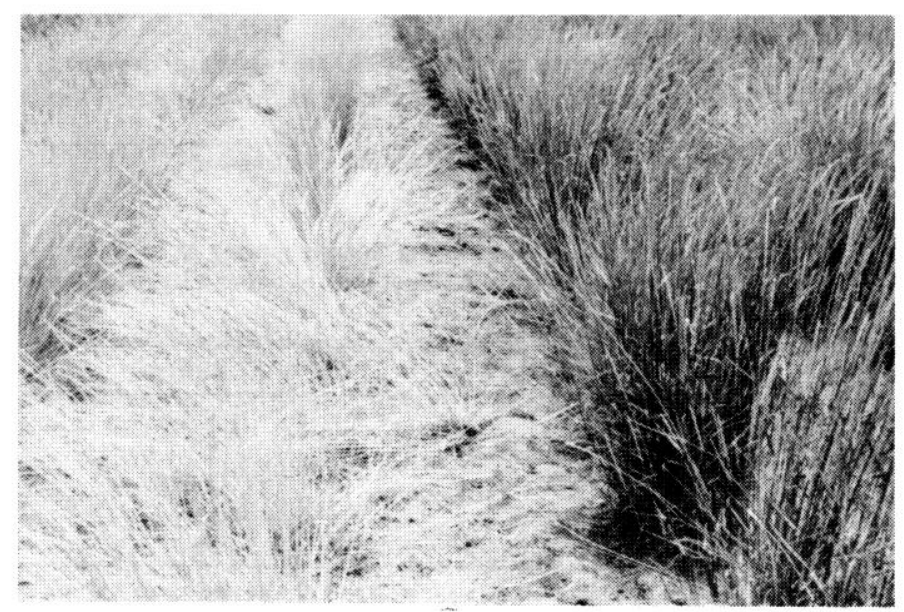

Fig. 1. Grass breeding nurseries at the Decker, Mont., surface mine. Left, slender wheatgrass severely damaged by the bluegrass billbug; right the Elytrigia repens $\times$ Et. spicata $(R S)$ hybrid relatively unaffected by the insect. 
Table 1. Average rated damage to range grass species and interspecific hybrids inflicted by the bluegrass billbug at the Decker, Montana surface mine.

\begin{tabular}{lclc}
\hline \hline Species or hybrid & Injury rating & Species or hybrid \\
\hline Agropyron cristatum R1 & 1.7 & L. triticoides & Injury rating \\
A. cristatum R2 & 2.8 & L. virginicus $\mathrm{M} 2$ & $\mathbf{0 . 6}$ \\
A. cristatum R3 & 2.8 & Hordeum violaceum & $\mathbf{8 . 4}$ \\
Elymus lanceolatus A1 & 2.3 & Et. repens $\times$ A. cristatumF1 \\
A. desertorum M138 & 2.3 & Et. repens $\times$ A. desertorum \\
E. trachycaulus A20 & 9.0 & Et. repens $\times$ Et. spicata 1 \\
Leymus ambiguus 1 & 1.7 & Et. repens $\times$ Et. spicata 2 \\
L. ambiguus 2 & 2.3 & Et. repens $\times$ Et. spicata 3 \\
Psathyrostachys juncea A27 & 1.1 & Et. repens $\times$ Et. spicata 4 \\
P. juncea V16 & 0 & E. trachycaulus $\times$ E. sitanion \\
L. salinae A9 & 0.6 & E. lanceolatus $\times$ P. juncea \\
L. salinae A10 & 1.1 & Mean \\
\hline
\end{tabular}

$\operatorname{LSD}(0.05)=2,45$

'Ratings: $0=$ least and $9=$ most damage - detached root system. Data based on 2 replications.

no damage and 9 severe damage (detached root system). The taxonomic nomenclature proposed by Dewey (1983) was used to describe grass species.

\section{Results and Discussion}

In the second year after planting (1979), the Decker nurseries were infested by a billbug identified as Sphenophorus parvulus. ${ }^{1}$ Significant differences in damage caused by the insect were evident among the breeding lines of grass species and hybrids in Nursery $A$. Larva feeding near the base of the crown severed major portions of the root system and completely devastated the stands of susceptible entries. Slender wheatgrass (Elymus trachycaulus) and related species, particularly those with the same genomic constitution (SSHH), were the most severely damaged. These species included $E$. donianus, $E$. fibrosus, $E$. mutabilus, $E$. sibiricus, and $E$. virginicus. Crested wheatgrass ( $A$. cristatum and $A$. desertorum), tall wheatgrass (Et. pontica), thickspike and streambank wheatgrass ( $E$. lanceolatus), western wheatgrass (Pascopurum smithii), altai wildrye (Leymus angustus), basin wildrye (L. cinereus), Russian wildrye (Psathyrostachys juncea), salina wildrye ( $L$. salinae), and several promising interspecific hybrids were relatively undamaged by the insect.

Initially, a 2,600-plant population of the $F_{7}$ generation of the RS hybrid included in Nursery $A$ was relatively undamaged by the insect (Fig. 1). However, moderate injury was observed among the hyrid plants after adjacent plots of slender wheatgrass and other susceptible species had been severely depleted. Genetic variability for resistance to the billbug was evident among breeding lines within the hybrid population, offering some encouragement that selection for resistance would be effective.

Ratings were made during July 1980 to estimate the relative damage to the 23 breeding lines included in nursery $B$ at Decker

Identified by C.W. O'Brien, Florida $A$ and $M$ Univ., Tallahassee, Fla.

Table 2. Summary of ratings for billbug damage among 46 Elytrigia repens $\times$ Et. spicata (RS) hybrid clonal lines at Miles City, Montana.

\begin{tabular}{lc}
\hline \hline Parameter & Ratings $^{1}$ \\
\hline Range in clonal means & $1.3-5.0$ \\
Grand mean & 3.1 \\
F (clonal lines) & $2.4^{* *}$ \\
S & 0.59 \\
Gen. Var. (\%) & 56 \\
\hline
\end{tabular}

Insect damage rated on individual plants from 0 to $9(0=$ no damage, $9=$ severe damage - detached root system). Data based on 10 replications.

* Significant at the 0.01 level of probability.
(Table 1). As was the case in the larger nursery, breeding lines differed significantly $(P<0.01)$ in resistance to the billbug. Feeding injury ranged from an average rating of 0 (essentially no damage) for a line of Russian wildrye to 9.0 (detached root system and plant death) for slender wheatgrass.

During August of 1981, the 46 clonal lines of the RS hybrid in the nursery at Miles City were infested with billbugs. Extensive ratings were made and significant $(P<0.01)$ differences were found among the clonal lines for resistance to the insect (Table 2). Some lines were essentially undamaged in all 10 replications, while others were moderately to severely affected. The genetic variance for resistance among the clonal lines accounted for $56 \%$ of the total phenotypic variance.

Although the data are still somewhat preliminary and parentprogeny relationships are yet to be studied, the opportunities for genetic improvement of resistance to the billbug appear to be excellent. Research is progressing to assess the damage attributable to the insect on western range and to develop laboratory and field procedures to identify resistant plant germplasm.

\section{Literature Cited}

Asay, K.H. 1979. Grasses for revegetation of surface mining areas in western U.S. Proc. Surface Coal Mining and Reclamation. Coal Conf. and Expo V. p. 155-159. McGraw-Hill. N.Y.

Asay, K.H., and D.R. Dewey. 1981. Registration of Agropyron repens $X$ A. spicatum germplasms RS-1 and RS-2 (Reg. No. GP11 and GP12). Crop Sci. 21:351.

Asny, K.H., D.A. Johnson, and D.R. Dewey. 1978. Breeding grasses for western range. Utah Sci. 39:3-5.

Brussell, G.E., and R.L. Clark. 1968. An evaluation of Baygon for control of the hunting billbug in a Zoysia grass lawn. J. Econ. Entomol. 61:1100.

Dewey, D.R. 1976. Derivation of a new forage grass from Agropyron repens $\times$ Agropyron spicatum hybrids. Crop Sci. 16:175-180.

Dewey, D.R. 1983. Historical and current taxonomic perspectives of Agropyron, Elymus, and related genera. Crop Sci. 23:637-642.

Kamm, J.A. 1969. Biology of the billbug Sphenophorus venatus confluens, a new pest of orchardgrass. J. Econ. Entomol. 62:808-812.

Kamm, J.A., and R.W. Every. 1969. Insecticides for control of Sphenophorus venatus confluens, Rhopalosiphum padi, and Rhipidothrips brunneus in orchardgrass. J. Econ. Entomol. 62:950-951.

Kindler, S.D., and E.J. Kinbacher. 1975. Differential reaction of Kentucky bluegrass cultivars to the bluegrass billbug, Sphenophorus parvulus Gyllenhal. Crop Sci. 15:873-874.

Niemczyk, H.D. and C. Frost. 1978. Insecticide resistance found in Ohio bluegrass billbugs. Ohio Rep. Res. Develop. 63:22-23.

Satterthwait, A.F.1931. Key to known pupae of the genus Calendra, with host-plant and distribution notes. Ann. Entomol. Soc. Amer. 24:143-172.

Tashiro, H., and K.E. Personius. 1970. Current status of the bluegrass billbug and its control in western New York home lawns. J. Econ. Entomol. 63:23-29. 